\title{
Development of Organic Briquettes From Slaughterhouse Waste as Nutrient Source for Plant Growth
}

\section{ARUN SANKAR K J ( $\sim$ arunsankarkj@gmail.com )}

College of Veterinary and Animal Sciences Mannuthy https://orcid.org/0000-0002-4152-3735

\section{N Vasudevan}

College of Veterinary and Animal Sciences Mannuthy

\section{B Sunil}

College of Veterinary and Animal Sciences Mannuthy

\section{A Latha}

KAU: Kerala Agricultural University

\section{Irshad A}

College of Veterinary and Animal Sciences Mannuthy

Deepak Mathew D. K

College of Veterinary and Animal Sciences Mannuthy

\section{Safeer M Saifudeen}

College of Veterinary and Animal Sciences Mannuthy

\section{Research Article}

Keywords: Organic briquettes, slaughterhouse wastes, rumen content, blood, coir pith, okra

Posted Date: April 27th, 2021

DOl: https://doi.org/10.21203/rs.3.rs-455771/v1

License: (a) This work is licensed under a Creative Commons Attribution 4.0 International License. Read Full License 
DEVELOPMENT OF ORGANIC BRIQUETTES FROM SLAUGHTERHOUSE WASTE AS NUTRIENT SOURCE FOR PLANT GROWTH

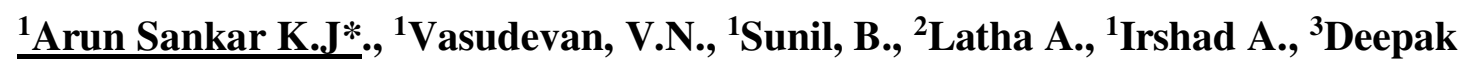
Mathew, D.K and ${ }^{4}$ Safeer M. Saifuddeen

1 - Department of Livestock Products Technology, College of Veterinary and Animal Sciences, Mannuthy, Kerala, India

2 - Agricultural Research Station, Kerala Agricultural University, Mannuthy, Kerala, India

3 - Department of Livestock Production Management, College of Veterinary and Animal Sciences, Mannuthy, Kerala, India

4 - Department of Animal Breeding, Genetics and Biostatistics, College of Veterinary and Animal Sciences, Mannuthy, Kerala, India

*Corresponding author: arunsankarkj@gmail.com 


\begin{abstract}
A study was conducted to develop organic briquettes using biomass originating from slaughterhouse wastes and to investigate its potential as a nutrient source for plant growth. Dried rumen contents were mixed with fresh blood collected after bleeding of animals in different proportions and dried using tray drier. The dried rumen content-blood (RB) mixture was further mixed with commercially available coir pith in 12 different proportions. The rumen content-blood-coir pith (RBC) mixture was formed into briquettes using a hydraulic biomass briquetting machine. Each organic briquette was $5 \mathrm{~cm}$ in diameter and had an average weight of 30-40 g. The treatments were analyzed for $\mathrm{pH}$, moisture content, electrical conductivity (EC), organic carbon (OC), total nitrogen, carbon: nitrogen ratio, total phosphorus and total potassium. Organic briquette having rumen content with $100 \%$ blood and $80 \%$ coir pith $\left(\mathrm{T}_{10}\right)$ recorded the highest total nitrogen, total phosphorus and total potassium content. The treatments for plant growth studies were selected based on the criteria that each treatment had highest values for at least two of the three primary nutrients of nitrogen, phosphorus and potassium. The treatments $\mathrm{T}_{5}, \mathrm{~T}_{7}, \mathrm{~T}_{8}, \mathrm{~T}_{10}$ and $\mathrm{T}_{12}$ were selected for plant growth studies. Pot experiment using selected briquettes was carried out to determine the effect of selected briquettes on growth parameters and yield attributes of okra (Abelmoschus esculentus). Nutrient release pattern of the selected organic briquettes was also studied. The best desirable growth parameters and yield attributes of okra was observed in $\mathrm{T}_{10}$. Availability of nutrients in the medium were relatively less during first two months of planting (MAP), however, it significantly increased between $3 \mathrm{MAP}$ and $4 \mathrm{MAP}$, which resulted in better plant growth and fruit yield. The study showed that there is great potential for development of organic briquettes using slaughter house wastes as an eco-friendly process, which are compact, easy to transport and market, and ideal for grow bag cultivation and garden nurseries.
\end{abstract}

Key words: Organic briquettes, slaughterhouse wastes, rumen content, blood, coir pith, okra 


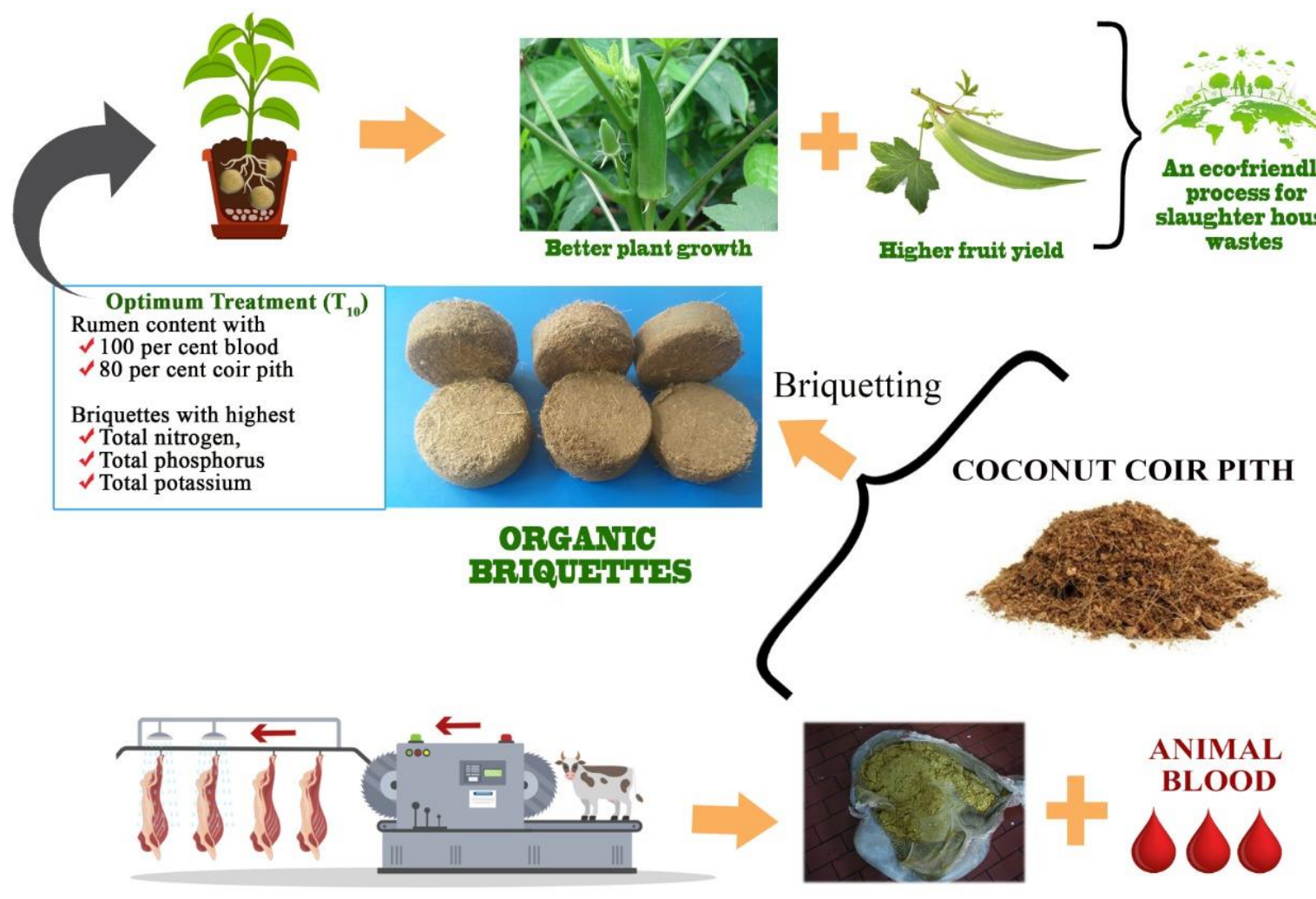




\section{STATEMENT OF NOVELTY}

This was the first study on the development of organic briquettes from slaughterhouse wastes and coir pith as nutrient source for plant growth which was shown to improve the growth and yield of okra. The work describes a cost-effective method for the utilization of slaughterhouse wastes using briquetting technology.

\section{INTRODUCTION}

Globally, India ranks first in terms of total livestock population. The ever-increasing demand for meat in the country over the course of decades led to an expansion of meat industry in terms of both number and capacity. In Kerala, a southern state in India, the total number of livestock handling units accounts to 15,680, out of which only 666 units operates with scientific waste disposal methods [1]. The total meat yield from cattle and buffaloes is approximately one third of the total live weight and the reminder comprises of by-products and wastes. The major inedible wastes include rumen contents and blood which constitutes approximately 16 $\%$ and $4 \%$ of the live weight of the animal respectively [2]. The current techniques for the disposal of rumen digesta such as ensiling and drying by fluid bed drier involves high processing and operational costs. If we let the blood to run off, it will clog the pipes and led to the generation of a high-level polluting effluent. The high protein content of blood makes it a difficult substrate for anaerobic digestion [3]. Existing methods for industrial processing of blood to produce good quality blood meal requires sophisticated technologies and are cost intensive.

Coir pith is a by-product of the coir industry which not only helps in upgrading the structure of the soil but also enhances the physical properties such as pore space, bulk density, hydraulic conductivity and infiltration rate of even the heaviest clay soils. The sponge like structure of coir pith aids in retention of water and it increases aeration in the root zone [4-5]. Composted coir pith is often used as growing medium in green houses, flower beds, garden nurseries and lawns.

Implementing technologically sophisticated operations to treat the complex waste (rumen contents and blood) would be exceedingly costly. Biomass briquetting is a process by which loose, high volume, low density materials (with moisture content less than $10 \%$ ) like agro residues are compacted into low volume and high-density masses by means of compression. The organic briquettes thus developed could be stored and transported easily [6]. 
These briquettes will be ideal for application in pot cultivation of vegetables in space restricted rural and urban settings, especially in the context of recent increasing popularity and acceptance for backyard and roof top cultivation in pots and grow bags. Investigations on the application of abattoir waste as an organic nutrient source is therefore a favourable proposition.

With this backdrop, the current study was undertaken to develop fertilizer briquettes by blending rumen content, blood and coir pith, to determine the chemical parameters of organic briquettes and to evaluate their agronomic performance in okra (Abelmoschus esculentus).

\section{METHODS AND MATERIALS}

\subsection{Development of organic briquettes from rumen contents, blood and coir pith}

Rumen contents and blood were collected from cattle and buffaloes slaughtered as per scientific slaughter procedures. Rumen contents were dried by keeping in a tray drier at $60^{\circ} \mathrm{C}$ for 18 hours. The moisture level of the dried rumen contents was estimated to be less than five $\%$ as per [7]. Fresh blood was added to the dried rumen contents at 60, 80 and $100 \%$ levels (w/w) over and above the weight of rumen content and mixed thoroughly. The rumen contentblood mixture (RB) was spread on a polythene sheet and sun dried for six hours. The partially dried $\mathrm{RB}$ was further dried in the tray drier at $60^{\circ} \mathrm{C}$ for nine hours. The moisture level of the combination was estimated to be less than five $\%$. The mixture was ground using a pulveriser. Coir pith purchased had electrical conductivity about $9 \mathrm{dS} / \mathrm{m}$. In order to reduce the electrical conductivity below $2 \mathrm{dS} / \mathrm{m}$, coir pith was washed twice using tap water.

A mixture of washed and dried coir pith and pre-processed RB was prepared containing coir pith at 60, 70, 80 and $90 \%(\mathrm{w} / \mathrm{w})$ levels to obtain 12 different treatments which were: $10 \%$ $\mathrm{RB}_{60}$ with $90 \%$ coir pith $\left(\mathrm{T}_{1}\right), 20 \% \mathrm{RB}_{60}$ with $80 \%$ coir pith $\left(\mathrm{T}_{2}\right), 30 \% \mathrm{RB}_{60}$ with $70 \%$ coir pith $\left(\mathrm{T}_{3}\right), 40 \% \mathrm{RB}_{60}$ with $60 \%$ coir pith $\left(\mathrm{T}_{4}\right), 10 \% \mathrm{RB}_{80}$ with $90 \%$ coir pith ( $\left.\mathrm{T}_{5}\right), 20 \% \mathrm{RB}_{80}$ with $80 \%$ coir pith $\left(\mathrm{T}_{6}\right), 30 \% \mathrm{RB}_{80}$ with $70 \%$ coir pith $\left(\mathrm{T}_{7}\right), 40 \% \mathrm{RB}_{80}$ with $60 \%$ coir pith $\left(\mathrm{T}_{8}\right), 10 \%$ $\mathrm{RB}_{100}$ with $90 \%$ coir pith ( $\left.\mathrm{T}_{9}\right), 20 \% \mathrm{RB}_{100}$ with $80 \%$ coir pith $\left(\mathrm{T}_{10}\right), 30 \% \mathrm{RB}_{100}$ with $70 \%$ coir pith $\left(\mathrm{T}_{11}\right)$ and $40 \% \mathrm{RB}_{100}$ with $60 \%$ coir pith $\left(\mathrm{T}_{12}\right)$. This final mixture was briquetted using a hydraulic briquetting machine to obtain briquettes which had $5 \mathrm{~cm}$ diameter and an average weight of 30-40 gm.

The 12 different treatments were analysed for $\mathrm{pH}$, moisture content, electrical conductivity (EC), organic carbon (OC) and carbon: nitrogen ratio [7] total nitrogen [8] and total phosphorus and total potassium as per [9].

After evaluating the physico-chemical parameters of organic briquettes belonging to 
the 12 treatments, the best five treatments for pot experiment were selected based on the criteria of higher nutrient contents for more than two primary nutrients of nitrogen, phosphorus and potassium. Based on this, $\mathrm{T}_{5}, \mathrm{~T}_{7}, \mathrm{~T}_{8}, \mathrm{~T}_{10}$ and $\mathrm{T}_{12}$ were selected for pot experiment.

\subsection{Effects of organic briquette on crop growth and yield}

Effects of organic briquettes made from slaughterhouse wastes on growth and yield of okra (Abelmoschus esculentus) were assessed by pot experiments conducted over a period of five months (February - June, 2020) at Agricultural Research Station, Kerala Agricultural University, Mannuthy.

\subsubsection{Soil characteristics}

$\mathrm{pH}$ and electrical conductivity of the soil were analysed as per Fertilizer Control Order [7]. Available nitrogen of the soil was determined by alkaline permanganometry [10]. Available phosphorus was estimated by extracting the soil samples with Bray No.1 solution followed by colorimetric estimation using reduced molybdate ascorbic acid blue colour method using Spectrophotometer (Model: lambda 25) [11]. The soil samples were extracted with neutral normal ammonium acetate and available potassium was estimated using Flame photometer (Model: CL 308) [12].

\subsubsection{Pot experiment}

The treatments $\mathrm{T}_{5}, \mathrm{~T}_{7}, \mathrm{~T}_{8}, \mathrm{~T}_{10}$ and $\mathrm{T}_{12}$ had the higher nutrient contents for more than two primary nutrients of nitrogen, phosphorus and potassium were selected for the pot experiment. All the selected combination of briquettes was replicated ten times. The treatments were randomly allocated to the pots following a completely randomized design. Ten replicates of control pots, containing no briquettes were also prepared. Grow bags having size 14 " $\times 16$ " were used as pots. Potting mixture (soil: perlite in the ratio $1: 1$ by volume and $10 \mathrm{~kg}$ weight) mixed with $10 \mathrm{~g}$ of pseudomonas was filled in each pot. Three briquettes each weighing 30-40 $\mathrm{g}$ was placed approximately $3 \mathrm{~cm}$ below the top layer. Perlite, an inert medium was used in potting mixture to increase the aeration in root zone. Nine days old seedlings of Arka Anamika variety of okra (Abelmoschus esculentus) were planted in each pot. Each pot was irrigated daily using equal quantities of tap water. After 21 days of planting the seedling, the supernatant liquid obtained from the fermentation of ground nut cake with nutrient composition of $7 \%$ nitrogen was applied at the rate of $10 \mathrm{ml}$ per plant uniformly to all plants as an additional nutrient supplement.

Morphological parameters such as height of the plant and number of leaves were recorded at one, two, three, four and five months after planting (MAP). The yield attributes of 
the plants including days to first flowering, number of flowers per plant, number of fruits, length and weight of the fruit from all the plants and fruit yield $(\mathrm{kg})$ per plant was recorded upto 5 MAP.

\subsection{NUTRIENT RELEASE PATTERN OF ORGANIC BRIQUETTES}

Three briquettes each of the selected treatments were placed in separate pots containing potting mixture (soil: perlite in the ratio $1: 1$ by volume) mixed with 10 gm of pseudomonas at a depth of about 3-4 $\mathrm{cm}$ and irrigated daily. Three soil samples per pot, at a depth of approximately $2-4 \mathrm{~cm}$ were taken at monthly interval for five months and analyzed for available nitrogen [10], available phosphorus [11] and available potassium [12].

\subsection{STATISTICAL ANALYSIS}

Data recorded were analysed statistically as per [13] by using SPSS Software (Version 24.0). Growth parameters and nutrient release pattern were analysed employing repeated measures ANOVA. Chemical properties of organic briquettes and yield attributes were analysed using one-way ANOVA.

\section{RESULTS AND DISCUSSION}

\subsection{Physico-chemical properties of briquettes}

The physico-chemical properties of different treatments of organic briquettes are presented in Table I.

\subsection{1 pH}

In the present study, various treatments of organic briquettes recorded $\mathrm{pH}$ in the range of 6.73 to 8.03 . Among the treatments, $\mathrm{T}_{8}$ and $\mathrm{T}_{6}$ had the highest and the lowest $\mathrm{pH}(8.03 \pm 0.09$ and $6.73 \pm 0.03$ ) as seen in Table 1 . The $\mathrm{pH}$ of the treatments was in compliance with the range of values prescribed [7] except $\mathrm{T}_{3}, \mathrm{~T}_{4}, \mathrm{~T}_{7}$ and $\mathrm{T}_{8}$. The $\mathrm{pH}$ of the cattle manure compost was observed to be 7.4 [14] and 7.3 [15], while the estimated $\mathrm{pH}$ of rumen contents used for preparing organic fertilizer was 8.0 [16]. The high $\mathrm{pH}$ could be attributed to the imbalance of nutrients inside the briquettes [17].

\subsubsection{Moisture}

The lowest moisture content $(6.62 \pm 0.15 \%)$ was recorded in $\mathrm{T}_{2}$ and the highest moisture content $(9.17 \pm 0.08 \%)$ was recorded in $\mathrm{T}_{12}$ as seen in Table 1 . The values of $\mathrm{T}_{2}$ were significantly $(p<0.05)$ different from all other treatments while $\mathrm{T}_{12}$ was not significantly different from other treatments except $\mathrm{T}_{1}$ and $\mathrm{T}_{2}$. The moisture content in the present study was 
in agreement with the values proposed [6-7] and [18] who stated that, moisture content less than $15 \%$ was ideal for briquetting. In another experiment, a high moisture content (>10\%), resulted in excess steam production, blocking the products from hopper and shooting out briquettes from dies [19].

\subsubsection{Electrical conductivity}

Electrical conductivity is a measure of salinity of soil. Among the treatments of organic briquettes, $\mathrm{T}_{5}$ had the lowest $(0.16 \pm 0.01 \mathrm{dS} / \mathrm{m})$ and $\mathrm{T}_{8}$ had the highest $(1.19 \pm 0.12 \mathrm{dS} / \mathrm{m})$ electrical conductivity as seen in Table 1. Electrical conductivity in the present study was similar to the values reported for cattle manure [20], but was lower than the values reported by [21] for cattle manure. The lower electrical conductivity values of the organic briquettes could be attributed due to the salts lost during drying of the rumen contents or during the washing of coir pith. An electrical conductivity greater than $2 \mathrm{dS} / \mathrm{m}$ restricted the growth of sensitive crops [22] and the briquettes used in the study were found to be in safe limit.

\subsubsection{Organic carbon}

As seen in Table 1, the organic carbon content was the highest for $\mathrm{T}_{8}(45.97 \pm 0.93 \%)$ and the lowest for $\mathrm{T}_{1}(39.24 \pm 0.77 \%)$ among the treatments under study. An organic carbon content of $16.6 \%$ was observed for cattle manure compost [15] and $29.32 \%$ in composted animal manure [23], while [24] reported an organic carbon content of $18.22 \%$ in bovine digesta mixed with tannery sludge. The reported values were lower when compared to the organic carbon content of briquettes used in the current study. Organic carbon content of cattle manure was scanty and the inclusion of lignocellulosic materials could equilibrize the under supply of carbon in cattle manure [25]. Coir pith had a high carbon content [26]. The high organic carbon content of the treatments used in the present study could be attributed due to the addition of high carbon content materials like coir pith in high proportions to the dried rumen contentblood mixture.

\subsubsection{Total nitrogen}

The organic briquettes, $\mathrm{T}_{10}$ and $\mathrm{T}_{1}$ had the highest $(1.76 \pm 0.09 \%)$ and the lowest $(0.92 \pm 0.09 \%)$ total nitrogen content respectively as seen in Table 1 . The total nitrogen content of the briquettes under study increased with increase in level of the blood added. Cattle manure compost had a total nitrogen content of $0.95 \%$ [15], which was lower than that of the organic briquettes used in the current study. This can be explained on the basis of the blood added during briquetting process which is an excellent protein source as it contains about $95 \%$ protein 
A high nitrogen content of $5.5 \%$ was observed in bovine blood- rumen digesta mixture in the ratio 3:1 [16], which was higher than the values of organic briquettes used in the present study. The lower nitrogen content observed in the current study could be due to the lower level of incorporation of blood in the rumen contents - blood mixture (1:1).

\subsubsection{Carbon: Nitrogen ratio}

The C: $\mathrm{N}$ ratio was the highest for $\mathrm{T}_{1}(43.44 \pm 4.50)$ and the lowest for $\mathrm{T}_{10}(24.29 \pm 1.05)$ as seen in Table 1. Organic briquettes made of bovine blood and rumen contents had a $\mathrm{C}: \mathrm{N}$ ratio of 4.8 [27], while granulated cattle manure compost had a C: $\mathrm{N}$ ratio of 17 [28]. The values observed in the present study was higher than the values mentioned in the above reports. A wide $\mathrm{C}$ : $\mathrm{N}$ ratio in the current study could be due to the addition of high amount of high carbon organic materials like coir pith. Coir pith had a wide C: N ratio of 100:1 [29]. The composting of raw coir pith with cattle manure and poultry waste could reduce the $\mathrm{C}$ : $\mathrm{N}$ ratio to 31.3 [5]. The $\mathrm{C}: \mathrm{N}$ ratio is an indication of immediate availability of nutrients and the $\mathrm{C}: \mathrm{N}$ ration of $\mathrm{T}_{10}$ was found to be favourable for the release of nutrients and thereby uptake of plants.

\subsubsection{Total phosphorus}

Total phosphorus content was the highest for $\mathrm{T}_{10}(1.52 \pm 0.07 \%)$ and the lowest for $\mathrm{T}_{6}$ $(0.79 \pm 0.06 \%)$ as seen in Table 1 . The phosphorus content of the organic briquettes used in the study were higher than the minimum recommended levels $(0.4 \%)$ prescribed by [7] and dried rumen contents $(0.69 \%)$ as reported by [30]. In the current study, higher levels of addition of blood in the rumen contents - blood mixture didn't cause comparable increase in the phosphorus content of the briquettes as blood is not a good source of phosphorus. There was no significant difference in the phosphorus content of rumen contents-blood mixture mixed in 1:1, 2:1 and 3:1 ratio as an organic fertilizer [16].

\subsubsection{Total potassium}

The potassium content of the organic briquettes was the highest for $\mathrm{T}_{10}(1.15 \pm 0.11 \%)$ and the lowest for $\mathrm{T}_{11}(0.55 \pm 0.18 \%)$ respectively as seen in Table 1 . The organic fertilizer developed from rumen contents had a potassium content of $0.17 \%$ [24]. The potassium content of bovine blood-rumen digesta mixture used as an organic fertilizer was $0.93 \%$ [16]. These values were considerably lower when compared to that of the potassium content of organic briquettes in the study. Coir pith is material possessing high potassium content [26]. The higher levels of potassium observed in the current study might be due to the incorporation of coir pith in the manufacture of briquettes. With increasing content of coir pith in 12 treatments, there 
was no comparable increase in the potassium content, though coir pith at four different levels were incorporated in these treatments. This could be due to the process of washing of coir pith which would have resulted in removal of a portion of potassium salts. The washing of coir pith has resulted in reduced the level of potassium salts [4]. 


\section{Table I. Chemical parameters of different organic briquettes prepared by addition of rumen content, blood and coir pith}

\begin{tabular}{|c|c|c|c|c|c|c|c|c|}
\hline Treatments & $\mathrm{pH}$ & $\begin{array}{c}\text { Moisture } \\
(\%)\end{array}$ & $\begin{array}{c}\text { Electrical } \\
\text { Conductivity } \\
\text { (dS/m) }\end{array}$ & $\begin{array}{c}\text { Organic } \\
\text { Carbon (\%) }\end{array}$ & $\begin{array}{c}\text { Total } \\
\text { Nitrogen } \\
(\%)\end{array}$ & $\begin{array}{c}\text { Carbon: } \\
\text { Nitrogen } \\
\text { ratio }\end{array}$ & $\begin{array}{c}\text { Total } \\
\text { Phosphorus } \\
\text { (\%) }\end{array}$ & $\begin{array}{c}\text { Total } \\
\text { Potassium } \\
(\%)\end{array}$ \\
\hline $\mathrm{T}_{1}$ & $7.13 \pm 0.03^{b c}$ & $6.80 \pm 0.12^{\mathrm{b}}$ & $0.29 \pm 0.01^{b}$ & $39.24 \pm 0.77^{\mathrm{a}}$ & $0.92 \pm 0.09^{\mathrm{a}}$ & $43.44 \pm 4.50^{c}$ & $0.80 \pm 0.03^{\mathrm{a}}$ & $0.78 \pm 0.05^{\mathrm{ab}}$ \\
\hline $\mathrm{T}_{2}$ & $7.43 \pm 0.03^{\mathrm{de}}$ & $6.62 \pm 0.15^{\mathrm{a}}$ & $0.33 \pm 0.02^{b}$ & $42.21 \pm 0.56^{\mathrm{abc}}$ & $1.20 \pm 0.09^{\mathrm{ab}}$ & $35.53 \pm 2.98^{b c}$ & $1.21 \pm 0.04^{\mathrm{c}}$ & $0.69 \pm 0.06^{\mathrm{ab}}$ \\
\hline $\mathrm{T}_{3}$ & $7.67 \pm 0.03^{\mathrm{f}}$ & $8.48 \pm 0.10^{\mathrm{bc}}$ & $0.41 \pm 0.01^{\mathrm{b}}$ & $40.91 \pm 0.78^{\mathrm{abc}}$ & $1.21 \pm 0.09^{\mathrm{ab}}$ & $34.23 \pm 2.89^{\mathrm{ab}}$ & $0.87 \pm 0.05^{\mathrm{ab}}$ & $0.71 \pm 0.08^{\mathrm{ab}}$ \\
\hline $\mathrm{T}_{4}$ & $7.53 \pm 0.03^{\mathrm{ef}}$ & $8.93 \pm 0.43^{b c}$ & $0.82 \pm 0.01^{\mathrm{d}}$ & $39.97 \pm 0.62^{\mathrm{ab}}$ & $1.38 \pm 0.16^{\mathrm{bc}}$ & $29.56 \pm 2.95^{\mathrm{ab}}$ & $0.87 \pm 0.06^{\mathrm{ab}}$ & $0.61 \pm 0.01^{\mathrm{ab}}$ \\
\hline $\mathrm{T}_{5}$ & $7.00 \pm 0.06^{b}$ & $8.15 \pm 0.57^{b c}$ & $0.16 \pm 0.01^{\mathrm{a}}$ & $43.93 \pm 1.59^{\mathrm{cd}}$ & $1.38 \pm 0.01^{\mathrm{bc}}$ & $31.77 \pm 1.27^{\mathrm{ab}}$ & $1.29 \pm 0.03^{c}$ & $0.84 \pm 0.12^{\mathrm{abc}}$ \\
\hline $\mathrm{T}_{6}$ & $6.73 \pm 0.03^{\mathrm{a}}$ & $8.56 \pm 0.04^{\mathrm{bc}}$ & $0.37 \pm 0.01^{b}$ & $41.76 \pm 1.07^{\mathrm{abc}}$ & $1.38 \pm 0.16^{\mathrm{bc}}$ & $30.84 \pm 2.86^{\mathrm{ab}}$ & $0.79 \pm 0.06^{\mathrm{a}}$ & $0.73 \pm 0.07^{\mathrm{ab}}$ \\
\hline $\mathrm{T}_{7}$ & $7.53 \pm 0.03^{\text {ef }}$ & $7.98 \pm 0.47^{\mathrm{bc}}$ & $0.83 \pm 0.03^{\mathrm{d}}$ & $41.76 \pm 0.77^{\mathrm{abc}}$ & $1.47 \pm 0.24^{\mathrm{bc}}$ & $29.63 \pm 4.06^{\mathrm{ab}}$ & $1.02 \pm 0.02^{\mathrm{b}}$ & $0.80 \pm 0.22^{\mathrm{abc}}$ \\
\hline $\mathrm{T}_{8}$ & $8.03 \pm 0.09^{g}$ & $8.90 \pm 0.25^{\mathrm{bc}}$ & $1.19 \pm 0.12^{\mathrm{e}}$ & $45.97 \pm 0.93^{\mathrm{d}}$ & $1.57 \pm 0.18^{\mathrm{bc}}$ & $30.03 \pm 3.54^{\mathrm{ab}}$ & $1.17 \pm 0.05^{\mathrm{c}}$ & $0.84 \pm 0.12^{\mathrm{abc}}$ \\
\hline $\mathrm{T}_{9}$ & $7.37 \pm 0.03^{\text {de }}$ & $8.96 \pm 0.32^{b c}$ & $0.31 \pm 0.01^{b}$ & $42.69 \pm 1.34^{\mathrm{bc}}$ & $1.49 \pm 0.10^{\mathrm{bc}}$ & $28.92 \pm 1.74^{\mathrm{ab}}$ & $1.01 \pm 0.03^{\mathrm{b}}$ & $0.76 \pm 0.06^{\mathrm{ab}}$ \\
\hline $\mathrm{T}_{10}$ & $7.47 \pm 0.09^{\mathrm{de}}$ & $9.13 \pm 0.11^{\mathrm{c}}$ & $0.39 \pm 0.01^{b}$ & $42.57 \pm 0.42^{\mathrm{bc}}$ & $1.76 \pm 0.09^{c}$ & $24.29 \pm 1.05^{\mathrm{a}}$ & $1.52 \pm 0.07^{\mathrm{d}}$ & $1.15 \pm 0.11^{\mathrm{c}}$ \\
\hline $\mathrm{T}_{11}$ & $7.30 \pm 0.06^{\mathrm{cd}}$ & $9.06 \pm 0.11^{\mathrm{c}}$ & $0.18 \pm 0.01^{\mathrm{a}}$ & $42.24 \pm 0.82^{\mathrm{abc}}$ & $1.58 \pm 0.09^{\mathrm{bc}}$ & $26.83 \pm 1.42^{\mathrm{ab}}$ & $1.00 \pm 0.04^{\mathrm{b}}$ & $0.55 \pm 0.18^{\mathrm{a}}$ \\
\hline $\mathrm{T}_{12}$ & $6.80 \pm 0.12^{\mathrm{a}}$ & $9.17 \pm 0.08^{c}$ & $0.65 \pm 0.02^{c}$ & $42.32 \pm 0.93^{\mathrm{abc}}$ & $1.48 \pm 0.18^{\mathrm{bc}}$ & $29.68 \pm 4.71^{\mathrm{ab}}$ & $1.45 \pm 0.08^{\mathrm{d}}$ & $0.95 \pm 0.08^{\mathrm{bc}}$ \\
\hline
\end{tabular}

Mean \pm S.E. of different treatments of organic briquettes with different alphabets as superscripts differ significantly at $p<0.05$ 


\subsection{Selection of organic briquettes for pot experiment}

The treatments $\mathrm{T}_{5}, \mathrm{~T}_{7}, \mathrm{~T}_{8}, \mathrm{~T}_{10}$ and $\mathrm{T}_{12}$ had higher nutrient contents for more than two primary nutrients of nitrogen, phosphorus and potassium for plant growth. Hence these treatments were selected for pot experiment.

\subsection{Effect of organic briquettes on crop growth and yield}

\subsubsection{Soil characteristics}

The soil used for the study was having a $\mathrm{pH}$ of 5.6 , electrical conductivity of $0.23 \mathrm{dS} / \mathrm{m}$, available nitrogen content of $175.61 \mathrm{~kg} / \mathrm{ha}$, available phosphorus content of $27.41 \mathrm{~kg} / \mathrm{ha}$ and available potassium content of $71.68 \mathrm{~kg} / \mathrm{ha}$.

\subsubsection{Growth parameters}

The growth parameters of okra are presented in Table II and Table III.

\subsubsection{Height of the plant}

As the number of months after planting (MAP) progressed, the height of okra plants supplemented with briquettes of all the five treatments showed an increasing trend. Plant growth reached its maximum at five MAP. At each MAP, the plant height was significantly higher than the previous months for $\mathrm{T}_{5}, \mathrm{~T}_{10}$ and $\mathrm{T}_{12}$. Maximum height $(136.87 \pm 2.58 \mathrm{~cm})$ was observed in $\mathrm{T}_{10}$ at five MAP and lowest height $(11.57 \pm 0.78 \mathrm{~cm})$ among all treatments were observed in control at one MAP. The height of okra plants at 72 days after sowing (DAS) was $69 \pm 0.1 \mathrm{~cm}$ by application of farmyard manure [31], while [32] reported a plant height of 56.94 $\mathrm{cm}$ at 55 DAS. The height of the plants observed in the current study was lower than these reports at two MAP which may be due to a slower release of nutrients readily available for absorption by plant roots during the initial stages due to a wide $\mathrm{C}: \mathrm{N}$ ratio.

\subsubsection{Number of leaves}

The number of leaves of okra by application of organic briquettes in the study showed an increasing pattern up to four months after planting and then decreased. Number of leaves showed a similar trend in all the treatments and control. Maximum number of leaves were seen in $\mathrm{T}_{10}(55.30 \pm 1.90)$ at four MAP and lowest number of leaves $(7.00 \pm 0.46)$ were seen in control at one MAP. The probable reason for increased number of leaves in $\mathrm{T}_{10}$ may be due to the increased supply of photosynthates for growth and due to increased nutrient content compared 
to other treatments [33]. Application of animal manure in pot culture of okra produced a higher number of leaves (58) in comparison to control where no animal manure was added [34]. The okra var. Arka Anamika had 58.7 leaves on an average at 120 DAS [35]. Both these findings were in line with the results obtained in the present work. The results indicated that manurebased applications could trigger vegetative growth in okra. The increased number of leaves upto 4 MAP indicated that the vegetative growth is maximum upto 4 months and hereafter translocation of photosynthates for fruit production was decreased.

\subsubsection{Yield attributes of okra}

The yield attributes of okra after the application of organic briquettes are presented in Table IV and V.

\subsubsection{Days to first flowering}

Days to first flowering was an important yield attribute as it influences earliness of flowering, number of pods per plant which in turn influences the fruit yield. In the study using selected organic briquettes, days to first flowering was minimum in $\mathrm{T}_{10}(33.90 \pm 0.50)$ and maximum in control $(42.70 \pm 0.40)$ and were significantly $(p<0.05)$ different. The increase in time required for first flowering could be due to the reduced availability of nutrient and resultant nutrient stress in control [36]. The presence of adequate quantity of nutrient sources for flower bud initiation in the treatment could have stimulated the differentiation of bud resulted in early flowering.

\subsubsection{Number of flowers per plant}

Number of flowers in okra plants under the influence of organic briquettes used in the study was maximum in $\mathrm{T}_{10}(36.50 \pm 0.48)$ and minimum in control $(15.10 \pm 0.48)$. The number of flowers obtained in $\mathrm{T}_{10}$ varied significantly $(p<0.05)$ from all other treatments. Phosphorus is a key element in plant reproduction and the availability of adequate levels of nutrients had a positive effect on crop production. The maximum number of flower buds obtained in okra by the application of cow dung was 30.2 [37] which was similar to the results obtained in the current study. The increased vegetative growth and translocation of photosynthates from source to sink might have contributed to higher number of flowers per plant.

\subsubsection{Number of fruits per plant}

The total number of fruits per plant had been widely considered as the most crucial factor determining the yield of okra. The treatment $\mathrm{T}_{10}$ recorded the highest number of fruits per plant (32.70 \pm 1.00$)$ in okra and control recorded the lowest number of fruits per plant 
(13.50 \pm 0.45$)$. Among the treatments applied, $\mathrm{T}_{10}$ had the highest nitrogen content. An increase in nitrogen was directly proportional to fruit production as nitrogen plays a vital role in assimilate production needed for photosynthesis [38]. The number of fruits obtained by the addition of cow dung as an organic nutrient source was 14.35 [39]. Application of farmyard manure at the rate of 10t/ha produced 10.62 fruits on average [35]. The values were slightly lower than the values recorded in the current work, which could be attributed due to the higher availability and uptake of nutrients by plants. The enhanced vegetative growth and higher number of flowers had resulted in higher fruit number and yield.

\subsubsection{Length and weight of the fruit}

The length of the fruits of okra were the highest in $\mathrm{T}_{10}(15.21 \pm 0.11 \mathrm{~cm})$ and the lowest in control $(13.37 \pm 0.09 \mathrm{~cm})$ and differed significantly $(p<0.05)$. Length of the fruits increased with increase in nutrient content of the briquettes. An increase in nitrogen content could enhance various biological processes in plants [40]. Weight of the fruits obtained by using organic briquette as a nutrient source was the highest for $\mathrm{T}_{10}(15.35 \pm 0.18 \mathrm{gm})$ and the lowest for control $(12.07 \pm 0.15 \mathrm{gm})$, with $\mathrm{T}_{10}$ differing significantly $(p<0.05)$ from all other treatments. Weight of the fruits increased with increasing nutrient content of the organic briquettes. Nitrogen level in the soil was positively related to fruit weight [41], which could be due to the increased fruit weight in treatments compared to control. The increased nitrogen, phosphorus and potassium content of the growth medium due to the addition of briquettes, increased the transfer and assimilation of photosynthates in plants, which consequently accelerated the formation of greater number of large sized fruits with greater number of seeds per fruit, leading to increased fruit weight [35].

\subsubsection{Total fruit yield per plant}

Fruit yield was an important attribute of okra as it is directly related to economics of production. The fruit yield of okra in the current study was the highest in $\mathrm{T}_{10}(0.501 \pm 0.17 \mathrm{~kg})$ and the lowest in control $(0.160 \pm 0.16 \mathrm{~kg})$. The fruits yield per plant is directly related to the number of fruits per plant and fruit weight [35] which underlines the reason for increased fruit yield in treatments compared to control. The increased fruit yield could also be attributed due to the increase in nitrogen levels [41]. The addition of organic manure to the soil in adequate amounts produced all the primary and secondary nutrients requires for crop growth [42]. Briquettes as organic nutrient sources might have improved physical and biological properties of the soil, subsequently increasing nutrient supply to plants, resulting in higher yield [43]. 
Table II. Effect of different treatments of organic briquettes on height of plant (cm) at different stages of growth

\begin{tabular}{cccccc}
\hline \multirow{2}{*}{ Treatments } & \multicolumn{4}{c}{ Height of the plant $(\mathrm{cm})$} \\
\cline { 2 - 6 } & $11.57 \pm 0.78^{\mathrm{Aa}}$ & $25.82 \pm 1.89^{\mathrm{Ab}}$ & $44.45 \pm 1.80^{\mathrm{Ac}}$ & $59.06 \pm 2.39^{\mathrm{Ad}}$ & $61.28 \pm 2.58^{\mathrm{Ad}}$ \\
\hline $\mathrm{C}$ & $18.68 \pm 0.78^{\mathrm{Ba}}$ & $31.34 \pm 1.89^{\mathrm{Bb}}$ & $74.48 \pm 1.80^{\mathrm{Bc}}$ & $104.05 \pm 2.39^{\mathrm{Bd}}$ & $107.82 \pm 2.58^{\mathrm{Be}}$ \\
\hline $\mathrm{T}_{5}$ & $18.93 \pm 0.78^{\mathrm{Ba}}$ & $40.00 \pm 1.89^{\mathrm{Cb}}$ & $76.64 \pm 1.80^{\mathrm{Bc}}$ & $107.63 \pm 2.39^{\mathrm{Bd}}$ & $110.19 \pm 2.58^{\mathrm{Bd}}$ \\
\hline $\mathrm{T}_{7}$ & $19.54 \pm 0.78^{\mathrm{Ba}}$ & $46.18 \pm 1.89^{\mathrm{Db}}$ & $88.29 \pm 1.80^{\mathrm{Cc}}$ & $125.80 \pm 2.39^{\mathrm{Cd}}$ & $128.29 \pm 2.58^{\mathrm{Cd}}$ \\
\hline $\mathrm{T}_{8}$ & $22.06 \pm 0.78^{\mathrm{Ca}}$ & $48.01 \pm 1.89^{\mathrm{Db}}$ & $94.20 \pm 1.80^{\mathrm{Dc}}$ & $131.56 \pm 2.39^{\mathrm{Cd}}$ & $136.87 \pm 2.58^{\mathrm{De}}$ \\
\hline $\mathrm{T}_{10}$ & $20.11 \pm 0.78^{\mathrm{BCa}}$ & $43.81 \pm 1.89^{\mathrm{CDb}}$ & $89.15 \pm 1.80^{\mathrm{CDc}}$ & $124.60 \pm 2.39^{\mathrm{Cd}}$ & $128.64 \pm 2.58^{\mathrm{Ce}}$ \\
\hline $\mathrm{T}_{12}$ & & & & $\mathbf{3} \mathbf{M A P}$ \\
\hline
\end{tabular}

Mean \pm S.E of different treatments having different superscripts (lower case letters a-e within rows, upper case letter A-D within columns) differ significantly $(p<0.05)$.

MAP - Months after planting 
Table III. Effect of different organic briquettes on number of leaves at different stages of growth

\begin{tabular}{cccccc}
\hline Treatments & \multicolumn{5}{c}{ Number of leaves } \\
\cline { 2 - 5 } & $\mathbf{1 ~ M A P}$ & $\mathbf{2 ~ M A P}$ & $\mathbf{3 ~ M A P}$ & $\mathbf{4}$ MAP & $\mathbf{5 ~ M A P ~}$ \\
\hline $\mathrm{C}$ & $7.00 \pm 0.46^{\mathrm{Aa}}$ & $10.60 \pm 0.72^{\mathrm{Ab}}$ & $12.60 \pm 1.13^{\mathrm{Abc}}$ & $13.50 \pm 1.90^{\mathrm{Abc}}$ & $10.50 \pm 0.97^{\mathrm{Ab}}$ \\
\hline $\mathrm{T}_{5}$ & $9.50 \pm 0.46^{\mathrm{Ba}}$ & $11.20 \pm 0.72^{\mathrm{Ab}}$ & $21.20 \pm 1.13^{\mathrm{Bd}}$ & $39.50 \pm 1.90^{\mathrm{Be}}$ & $16.20 \pm 0.97^{\mathrm{Bc}}$ \\
\hline $\mathrm{T}_{7}$ & $10.00 \pm 0.46^{\mathrm{BCa}}$ & $13.60 \pm 0.72^{\mathrm{Bb}}$ & $22.70 \pm 1.13^{\mathrm{Bd}}$ & $41.20 \pm 1.90^{\mathrm{Be}}$ & $18.40 \pm 0.97^{\mathrm{Bc}}$ \\
\hline $\mathrm{T}_{8}$ & $10.40 \pm 0.46^{\mathrm{BCa}}$ & $14.30 \pm 0.72^{\mathrm{Bb}}$ & $32.10 \pm 1.13^{\mathrm{Cd}}$ & $50.80 \pm 1.90^{\mathrm{Ce}}$ & $22.00 \pm 0.97^{\mathrm{Cc}}$ \\
\hline $\mathrm{T}_{10}$ & $11.10 \pm 0.46^{\mathrm{Ca}}$ & $14.80 \pm 0.72^{\mathrm{Bb}}$ & $37.20 \pm 1.13^{\mathrm{Dd}}$ & $55.30 \pm 1.90^{\mathrm{De}}$ & $27.80 \pm 0.97^{\mathrm{Dc}}$ \\
\hline $\mathrm{T}_{12}$ & $10.50 \pm 0.46^{\mathrm{BCa}}$ & $13.70 \pm 0.72^{\mathrm{Bb}}$ & $33.10 \pm 1.13^{\mathrm{Cd}}$ & $51.60 \pm 1.90^{\mathrm{Ce}}$ & $23.00 \pm 0.97^{\mathrm{Cc}}$ \\
\hline
\end{tabular}

Mean \pm S.E of different treatments having different superscripts (lower case letters a-e within rows, upper case letter A-D within columns) differ significantly $(p<0.05)$.

MAP - Months after planting 
Table IV. Effect of different composition of organic briquettes on days to first flowering, number of flowers and number of fruits in Okra

\begin{tabular}{cccc}
\hline Treatments & $\begin{array}{c}\text { Days to first } \\
\text { flowering }\end{array}$ & Number of flowers & Number of fruits \\
\hline $\mathrm{C}$ & $42.70 \pm 0.40^{\mathrm{d}}$ & $15.10 \pm 0.48^{\mathrm{a}}$ & $13.50 \pm 0.45^{\mathrm{a}}$ \\
\hline $\mathrm{T}_{5}$ & $36.50 \pm 0.48^{\mathrm{b}}$ & $21.90 \pm 0.69^{\mathrm{b}}$ & $20.60 \pm 0.54^{\mathrm{b}}$ \\
\hline $\mathrm{T}_{7}$ & $35.60 \pm 0.48^{\mathrm{bc}}$ & $22.80 \pm 0.63^{\mathrm{b}}$ & $20.70 \pm 0.56^{\mathrm{b}}$ \\
\hline $\mathrm{T}_{8}$ & $34.90 \pm 0.38^{\mathrm{ab}}$ & $27.30 \pm 0.83^{\mathrm{c}}$ & $24.90 \pm 0.77^{\mathrm{c}}$ \\
\hline $\mathrm{T}_{10}$ & $33.90 \pm 0.50^{\mathrm{a}}$ & $34.70 \pm 1.03^{\mathrm{e}}$ & $32.70 \pm 1.00^{\mathrm{e}}$ \\
\hline $\mathrm{T}_{12}$ & $34.60 \pm 0.45^{\mathrm{ab}}$ & $31.10 \pm 0.71^{\mathrm{d}}$ & $29.10 \pm 0.60^{\mathrm{d}}$ \\
\hline
\end{tabular}

Mean \pm S.E. of different treatments having different alphabets as superscripts differ significantly $(p<0.05)$.

Table V. Effect of different composition of organic briquettes on length and weight of fruits and fruit yield in okra

\begin{tabular}{cccc}
\hline Treatments & $\begin{array}{c}\text { Length of fruit } \\
(\mathrm{cm})\end{array}$ & $\begin{array}{c}\text { Weight of fruit } \\
(\mathrm{g})\end{array}$ & $\begin{array}{c}\text { Fruit yield }(\mathrm{kg}) \\
\text { per plant }\end{array}$ \\
\hline $\mathrm{C}$ & $13.37 \pm 0.09^{\mathrm{a}}$ & $12.07 \pm 0.15^{\mathrm{a}}$ & $0.160 \pm 0.16^{\mathrm{a}}$ \\
\hline $\mathrm{T}_{5}$ & $13.73 \pm 0.08^{\mathrm{a}}$ & $12.82 \pm 0.14^{\mathrm{b}}$ & $0.263 \pm 0.75^{\mathrm{b}}$ \\
\hline $\mathrm{T}_{7}$ & $14.48 \pm 0.49^{\mathrm{b}}$ & $13.56 \pm 0.50^{\mathrm{c}}$ & $0.280 \pm 0.17^{\mathrm{b}}$ \\
\hline $\mathrm{T}_{8}$ & $15.09 \pm 0.12^{\mathrm{bc}}$ & $14.61 \pm 0.16^{\mathrm{d}}$ & $0.363 \pm 0.27^{\mathrm{c}}$ \\
\hline $\mathrm{T}_{10}$ & $15.21 \pm 0.11^{\mathrm{c}}$ & $15.35 \pm 0.18^{\mathrm{e}}$ & $0.501 \pm 0.17^{\mathrm{e}}$ \\
\hline $\mathrm{T}_{12}$ & $14.88 \pm 0.10^{\mathrm{bc}}$ & $14.13 \pm 0.17^{\mathrm{cd}}$ & $0.410 \pm 0.87^{\mathrm{d}}$ \\
\hline
\end{tabular}

Mean \pm S.E. of different treatment having different alphabets as superscripts differ significantly, $(p<0.05)$. 


\subsubsection{Nutrient release pattern of organic briquettes}

The growth and yield of plants depends on the availability of nutrients in the medium. Effect of different treatments of organic briquettes on available nitrogen, phosphorus and potassium at different stages of plant growth followed a similar pattern and are represented in Figure I, II and III respectively. The maximum available nutrient content was seen at four MAP and minimum was seen at one MAP with significant $(p<0.05)$ increase noted between three MAP and four MAP. Delayed nitrogen release was noticed in composted pellets in comparison with ordinary composts [18]. Due to the prevalence of anaerobic conditions inside the pellet, nitrification increases which become more evident in larger pellets. Similarly, slower release of nitrogen into the medium was observed in the current study. Organic materials having wide $\mathrm{C}$ : $\mathrm{N}$ ratio and high lignin content favour nutrient immobilisation rather than mineralisation [44]. Coir pith had high carbon: nitrogen ratio and lignin content [29]. The organic briquettes used in the study had a wide $\mathrm{C}$ : $\mathrm{N}$ ratio and had coir pith added in high amounts which could be the reason for slower nitrogen release during first two MAP.

In a study of application of bovine blood-rumen digesta mixture as a supplement for tomato cultivation, [27] also observed lower release of nitrogen at two weeks after planting compared to that of four weeks after planting. Similarly, maximum available nitrogen, phosphorus and potassium content in the soil were noticed after 45 days of application, when bovine digesta was added to the soil in raw form [45].

At all stages of growth, the lowest available nutrient content was noticed in $\mathrm{T}_{5}$ and the highest values were noted in $\mathrm{T}_{10}$. The available potassium and phosphorus contents in the soil increased with increase in rate of application of the organic fertilizer used [16,24]. The treatment $\mathrm{T}_{10}$ had more nutrient content compared to other treatments which might have contributed to the increased nutrient availability at different stages of growth. A combination of organic manures positively influenced the available NPK content of media which might be due to the added supply of nutrients [46]. The availability of nutrients in soil was markedly higher in treatment where blood and rumen contents were added in the ratio 3:1 compared to the treatments where blood and rumen contents are added in 2:1 and 1:1 ratio [16]. The nutrient release study indicated that the release pattern showed an increasing trend upto 4 MAP which coincides with maximum vegetative growth of okra. 
Fig. I Effect of organic briquettes on available nitrogen $(\mathrm{kg} / \mathrm{ha})$ content of medium

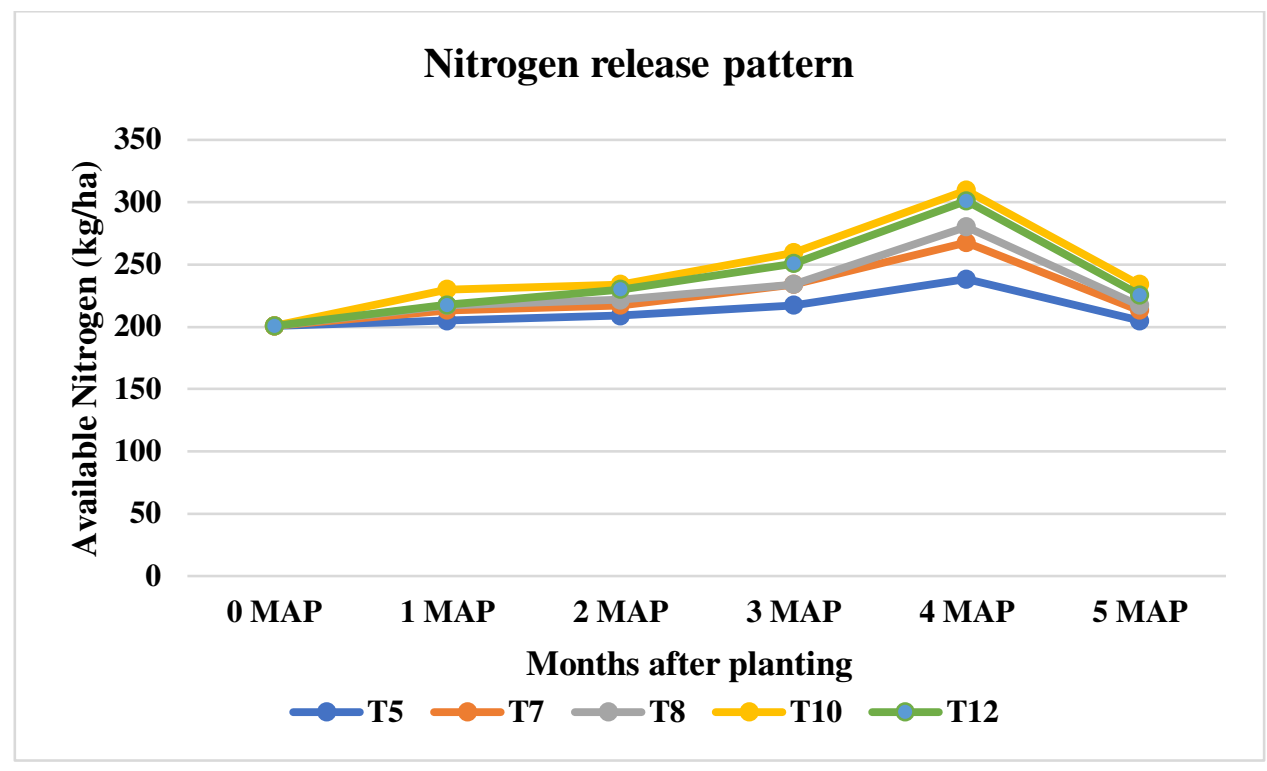

Fig. II Effect of organic briquettes on available phosphorus (kg/ha) content of medium

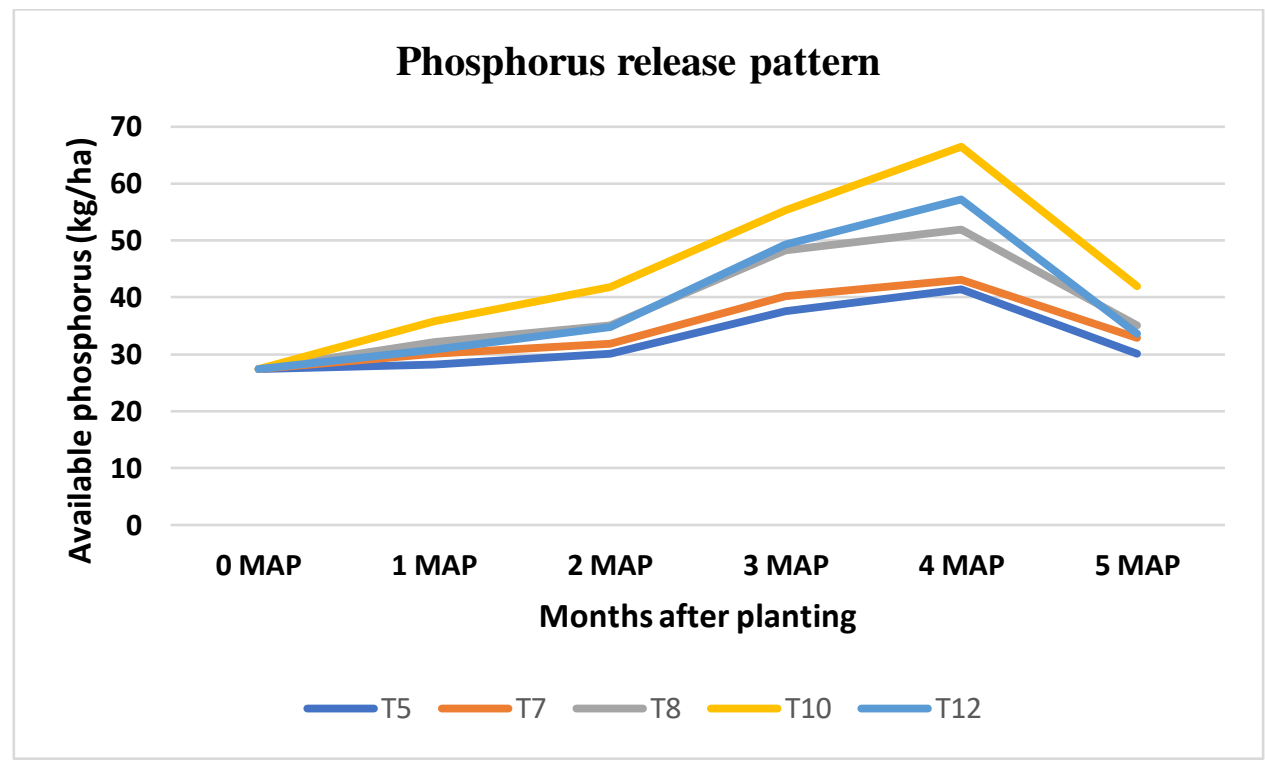


Fig. III Effect of organic briquettes on available potassium (kg/ha) content of medium

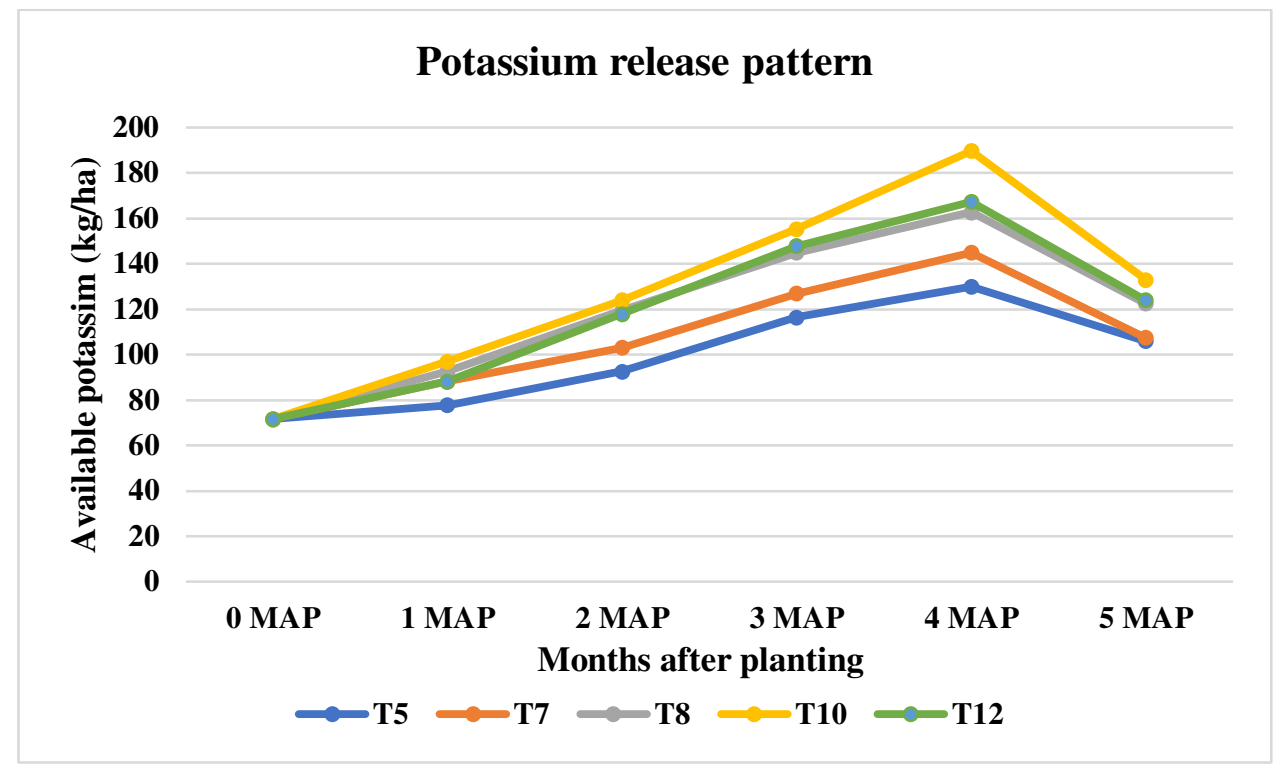

\section{CONCLUSION}

The current study has revealed that compact organic briquettes developed using preprocessed rumen content-blood and coir pith have great potential to be used as a plant growth supplement in pot culture or grow bag cultivation of vegetables. The best desirable plant growth and fruit yield parameters were observed, when organic briquettes having $20 \% \mathrm{RB} 100$ and $80 \%$ coir pith $\left(\mathrm{T}_{10}\right)$ were utilised as an organic nutrient source. Three such briquettes were applied into each pot or grow bag of okra. The availability of nutrient in the medium was relatively low in the initial phase of crop growth. However, at four MAP, higher levels of nutrients were available in the medium which resulted in better plant growth and fruit yield. The organic briquettes are an effective means for nutrient supply in pot culture especially in terrace garden for vegetables. The importance of developing briquettes from slaughterhouse wastes is underscored by the fact that, these two waste materials contribute greatest towards the environmental impact of service slaughterhouses and the consequent public dissent in Kerala. Large volume, cost effective equipment like solar driers can be utilised for preprocessing of rumen contents and blood. In smaller slaughterhouses, the dried rumen content can be directly used to receive blood from the bleeding animal in prescribed proportions, which eliminates the problem of run off of blood into the drainage and to the outside of the slaughterhouse. The development of organic briquettes is a viable 
option in the present context of lack of practical ways and means for waste disposal and organic agriculture in Kerala. The scope for further refinement of the work includes development of suitable methods of pre-processing of raw materials to improve the release of nutrients in the medium, analysis of briquettes for micro nutrients and suitable amendments if needed, enrichment with other organic materials to improve release efficiency of nutrients and the evaluating the effect of briquettes on the growth and yield parameters of other crops before field application.

\section{REFERENCES}

1. ECOSTAT.: Results of the survey. Available: http://www.ecostat.kerala.gov.in/images/pdf/publications/Survey Studies/data/rep sv y_slaugher_house_2013.pdf (2014). Accessed 21 October 2020

2. Irshad, A., Sureshkumar, S., Shukoor, S.A., Sutha, M.: Slaughter house by-product utilization for sustainable meat industry-a review. Int. J. Dev. Res. 5, 4725-4734 (2015).

3. Salminen, E., Rintala, J.: Anaerobic digestion of organic solid poultry slaughterhouse waste-a review. Bioresour. Technol. 83, 13-26 (2002)

4. Jeyaseeli, D.M., Raj, S.P.: Chemical characteristics of coir pith as a function of its particle size to be used as soilless medium. Ecoscan, 4, 163-169 (2010)

5. Muthurayar, T., Dhanarajan, M.S.: Biochemical changes during composting of coir pith waste as influenced by different agro industrial wastes. Agric. Sci. 4, 28-30 (2013)

6. Dubey, K., Upadhyay, V.K., Pandey, A.: Briquetting of biomass. Everyman's Sci. 10, 223-226 (2010)

7. FCO [Fertilizer Control Order].: Specifications of biofertilizers. Ministry of Agriculture and Rural Development, Government of India, New Delhi (1985)

8. Prasannakumar, B.: Aerobic and anaerobic digestion of agricultural waste followed by vermicomposting and enrichment. M.Sc. thesis, 83p. Professor Jayashankar Telangana State Agricultural University, Hyderabad (2016)

9. Jackson, M.L.: Soil chemical analysis. Hall of India Private Limited, New Delhi (1967)

10. Subbiah, B. V., Asija, G. L.: A rapid procedure for estimation of available nitrogen in soil. Curr. Sci. 25, 259-260 (1956)

11. Bray, R.H., Kurtz, L. T.: Determining total organic and available forms of phosphate in soil. Soil Sci. 59, 39-45 (1945)

12. Jackson, M. L.: Soil chemical analysis. Printice hall Inc, New Jersey (1958) 
13. Snedecor, G.W., Cochran, W.G.: Statistical methods. Iowa state University Press, Ames, Iowa, USA (1994)

14. Irshad, M., Eneji, A.E., Hussain, Z., Ashraf, M.: Chemical characterization of fresh and composted livestock manures. J. Soil Sci. Plant Nutr. 13, 115-121 (2013)

15. Khater, E.S.G.: Some physical and chemical properties of compost. Int. J. Waste Resour. 5, 1-5 (2015)

16. Roy, M., Karmakar, S., Debsarcar, A., Sen, P.K., Mukherjee, J.: Application of rural slaughterhouse waste as an organic fertilizer for pot cultivation of solanaceous vegetables in India. Int. J. Recycling Org. Waste Agric. 2, 6-23 (2013)

17. Pennisi, S.V., Thomas, P.A.: Essential pH management in greenhouse crops-part 1: pH and plant nutrition. Cooperative Extension Bulletin No. 1256, University of Georgia, Athens (2009)

18. Hara, M.: Fertilizer pellets made from composted livestock manure. Extension Bulletin Issue No. 6, Food \& Fertilizer Technology Center, Taiwan (2001)

19. Grover, P.D., Mishra, S.K.: Biomass briquetting: technology and practices. Field Document No. 46. FAO Regional Wood Energy Development Programme in Asia, Bangkok (1996)

20. Azeez, J.O., Van Averbeke, W.: Dynamics of soil pH and electrical conductivity with the application of three animal manures. Commun. Soil Sci. Pl. Anal. 43, 865-874 (2012)

21. Han, S.H., An, J.Y., Hwang, J., Kim, S.B., Park, B.B.: The effects of organic manure and chemical fertilizer on the growth and nutrient concentrations of yellow poplar (Liriodendron tulipifera) in a nursery system. Forest Sci. Technol. 12, 137-143 (2016)

22. Das, D.K.: Introductory Soil Science. Kalyani Publishers, New Delhi (2011)

23. Tripetchkul, S., Pundee, K., Koonsrisuk, S., Akeprathumchai, S.: Co-composting of coir pith and cow manure: initial $\mathrm{C} / \mathrm{N}$ ratio vs physico-chemical changes. Int. J. Recycling Org. Waste Agric. 1, 15-23 (2012)

24. Nunes, W.A.G., Menezes, J.F.S., de Melo Benites, V., de Lima Junior, S.A., dos Santos Oliveira, A.: Use of organic compost produced from slaughterhouse waste as fertilizer in soybean and corn crops. Sci. Agric. 72, 343-350 (2015)

25. Font-Palma, C.: Methods for the treatment of cattle manure-a review. C-J. Carbon Res. 5, 27-38 (2019) 
26. Abad, M., Noguera, P., Puchades, R., Maquieira, A., Noguera, V.: Physico-chemical and chemical properties of some coconut coir dust for use as a peat substitute for containerised ornamental plants. Bioresour. Technol. 82, 241-245 (2002)

27. Roy, M., Das, R., Debsarcar, A., Sen, P.K., Mukherjee, J.: Conversion of rural abattoir wastes to an organic fertilizer and its application in the field cultivation of tomato in India. Renew. Agric. Food Syst. 31, 350-360 (2015)

28. Mieldazys, R., Jotautienè, E., Jasinskas, A., Pekarskas, J., Zinkeviciene, R.: Investigation of physical-mechanical properties and impact on soil of granulated manure compost fertilizers. J. Environ. Engng. Landsc. Mgmt. 27, 153-162 (2019)

29. Prabhu, S.R., Thomas, G.V.: Biological conversion of coir pith into a value-added organic resource and its application in Agri-Horticulture: Current status, prospects and perspective. J. Plant. Crops. 30, 1-17 (2002)

30. Elfaki, M.O.A., Abdelatti, K.A.: Nutritive evaluation of rumen content from cattle, camel, sheep and goat. Global J. Anim. Sci. Res. 3, 617-621 (2015)

31. Attarde, S.B., Narkhede, S.D., Patil, R.P., Ingle, S.T.: Effect of organic and inorganic fertilizers on the growth and nutrient content of Abelmoschus esculentus (okra crop). Int. J. Curr. Res. 4, 137-140 (2012)

32. Adhikari, A., Piya, A.: Effect of different sources of nutrient on growth and yield of okra (Abelmoschus esculentus L. Monech). Int. J. Environ. Agric. Res. 6, 45-50 (2012)

33. Jangde, S.K., Jaiswal, R.K., Jangde, S., Kurre, D.K.: Impact of different varieties/hybrids of okra [Abelmoschus esculentus (L.) Moench.] on yield and Growth parameters under late sown condition of Malwa region. The Pharm. Innov. (2019)

34. Gulshan, A.B., Saeed, H.M., Shazia, J., Tooba, M., Atta, M.I., Muhammad, A.U.D. Effects of animal manure on the growth and development of okra (Abelmoschus esculentus). J. Agric. Biol. Sci. 8, 213-218 (2013)

35. Rajesh, J., Prasad, V.M., Banothu, L.N. Evaluation of Okra [Abelmoschus esculentus (L.) Moench] hybrids for growth parameters under Allahabad agro climatic condition. J. Pharmacogn. Phytochem. 7, 1813-1816 (2018)

36. Mal, B., Mahapatra, P., Mohanty, S., Mishra, H.N.: Growth and yield parameters of okra (Abelmoschus esculentus) influenced by Diazotrophs and chemical fertilizers. J. Crop Weed. 9, 109-112 (2013)

37. Uddin, M.J., Akand, M., Islam, S., Mehraj, H., Jamal Uddin, A.F.M.: Phosphorus levels on growth and yield of okra (Abelmoschus esculentus). Bangladesh Res. Publ. J. 10, $120-124(2014)$ 
38. Ayissaa, T., Kebede, F.: Effect of nitrogenous fertilizer on the growth and yield of cotton (Gossypium hirsutum L.) varieties in middle Awash, Ethiopia. J. Drylands. 4, 248-258 (2011)

39. Gudugi, I.A.S.: Effects of cow dung and variety on the growth and yield of Okra (Abelmoschus esculentus). Eur. J. Exp. Biol. 3, 495-498 (2013)

40. Santos, H.C., Pereira, E.M., de Medeiros, R.L., Costa, P.M.D.A., Pereira, W.E.: Production and quality of okra produced with mineral and organic fertilization. Rev. Bras. Eng. Agric. Ambient. 23, 97-102 (2019)

41. Brar, N.S., Singh, D.: Impact of nitrogen and spacing on the growth and yield of okra [Abelmoschus esculentus (L.) Moench]. J. Pure Appl. Microbiol. 6, 1-7 (2016)

42. Nweke, I.A., Ijearu, S.I., Igili, D.N.: Effect of different sources of animal manure on the growth and yield of okra (Abelmoschus esculentus L. Moench) in Ustoxic Dystropept at Enugu South Eastern, Nigeria. J. Sci. Technol. Res. 2, 135-137 (2013)

43. Premsekhar, M., Rajashree, V.: Influence of organic manures on growth, yield and quality of okra. Am. Eurasian J. Sustain. Agric. 3, 6-8 (2009)

44. Adekiya, A., Ejue, W.S., Olayanju, A., Dunsin, O., Aboyeji, C.M., Aremu, C., Adegbite, K., Akinpelu, O.: Different organic manure sources and NPK fertilizer on soil chemical properties, growth, yield and quality of okra. Sci. Rep. 10, 160-169 (2020)

45. Meignanalakshmi, S., Charulatha, M., Vennila, C., Gnanaraj, P.T., Pandian, A.S.S., Vijayarani, K.: Evaluation of Bovine Digesta as Organic Fertilizer in Maize Using Pot Experiments. Int. J. Curr. Microbiol. App. Sci. 7, 506-516 (2018)

46. Akhila, N., Kumari, A., Nayak, M.H., Vijaya, D.: Impact of organic manures and biofertilizers on available NPK in soil and nutrient composition of okra fruit. Int. J. Curr. Microbiol. App. Sci. 8, 622-623 (2019)

\section{DECLARATIONS}

- Funding - Kerala Veterinary and Animal Sciences University, Pookode

- Conflicts of interest/Competing interests: Not applicable

- Ethics approval: Not applicable

- Consent to participate: Not applicable

- Consent for publication: Not applicable

- Availability of data and material: Not applicable

- Code availability: Not applicable 
Figures

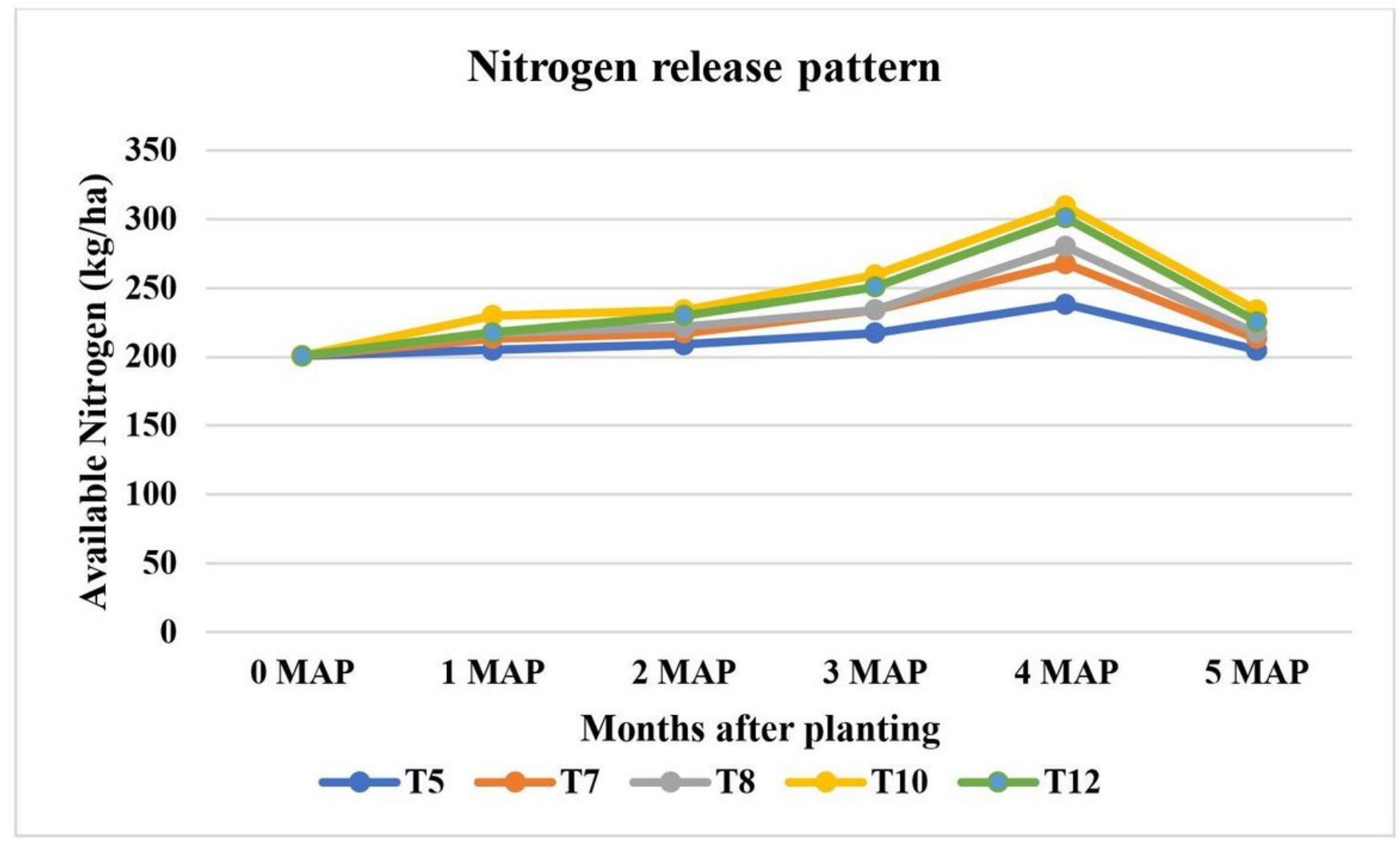

Figure 1

Effect of organic briquettes on available nitrogen $(\mathrm{kg} / \mathrm{ha})$ content of medium 


\section{Phosphorus release pattern}

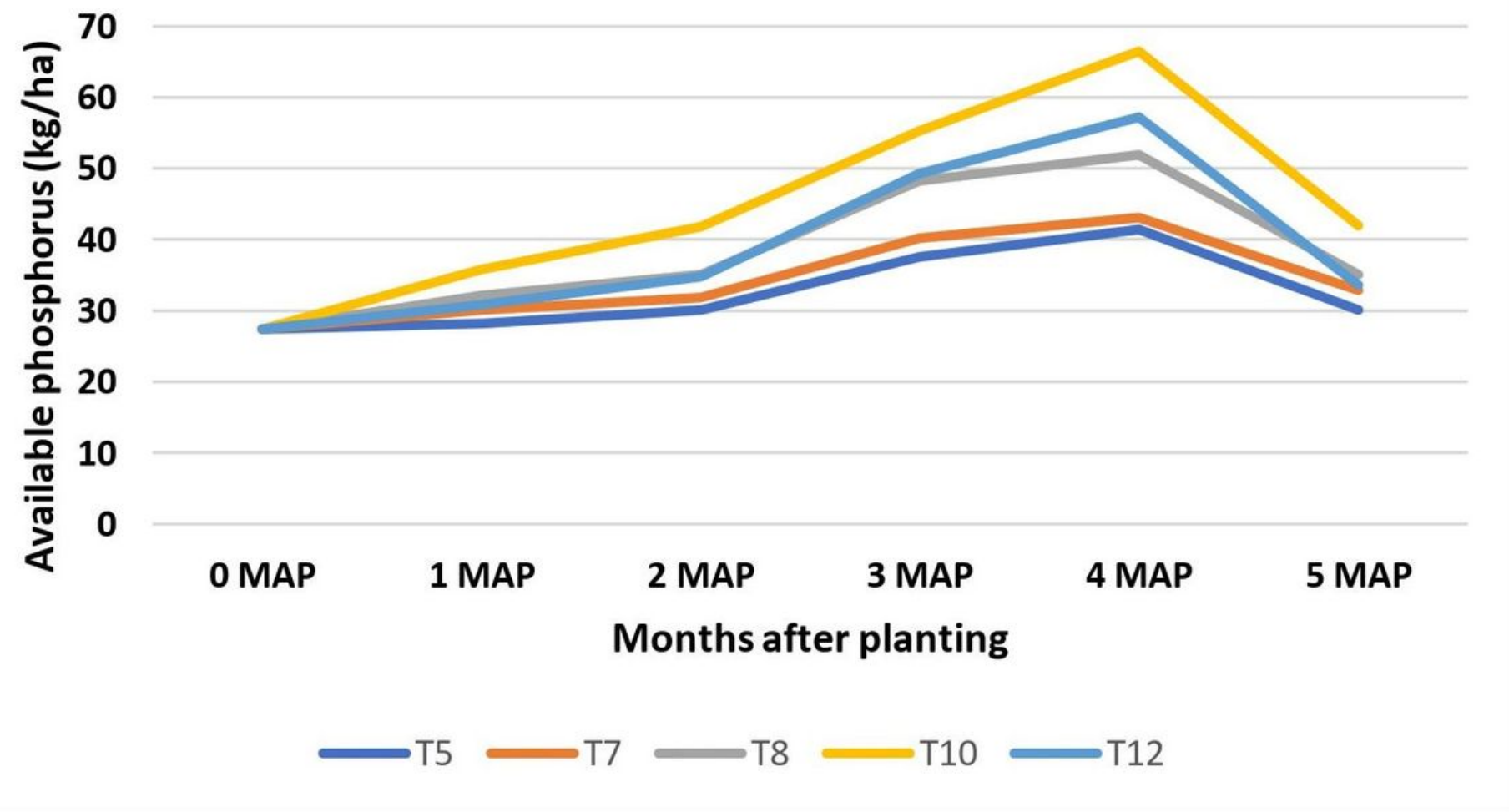

Figure 2

Effect of organic briquettes on available phosphorus $(\mathrm{kg} / \mathrm{ha})$ content of medium 


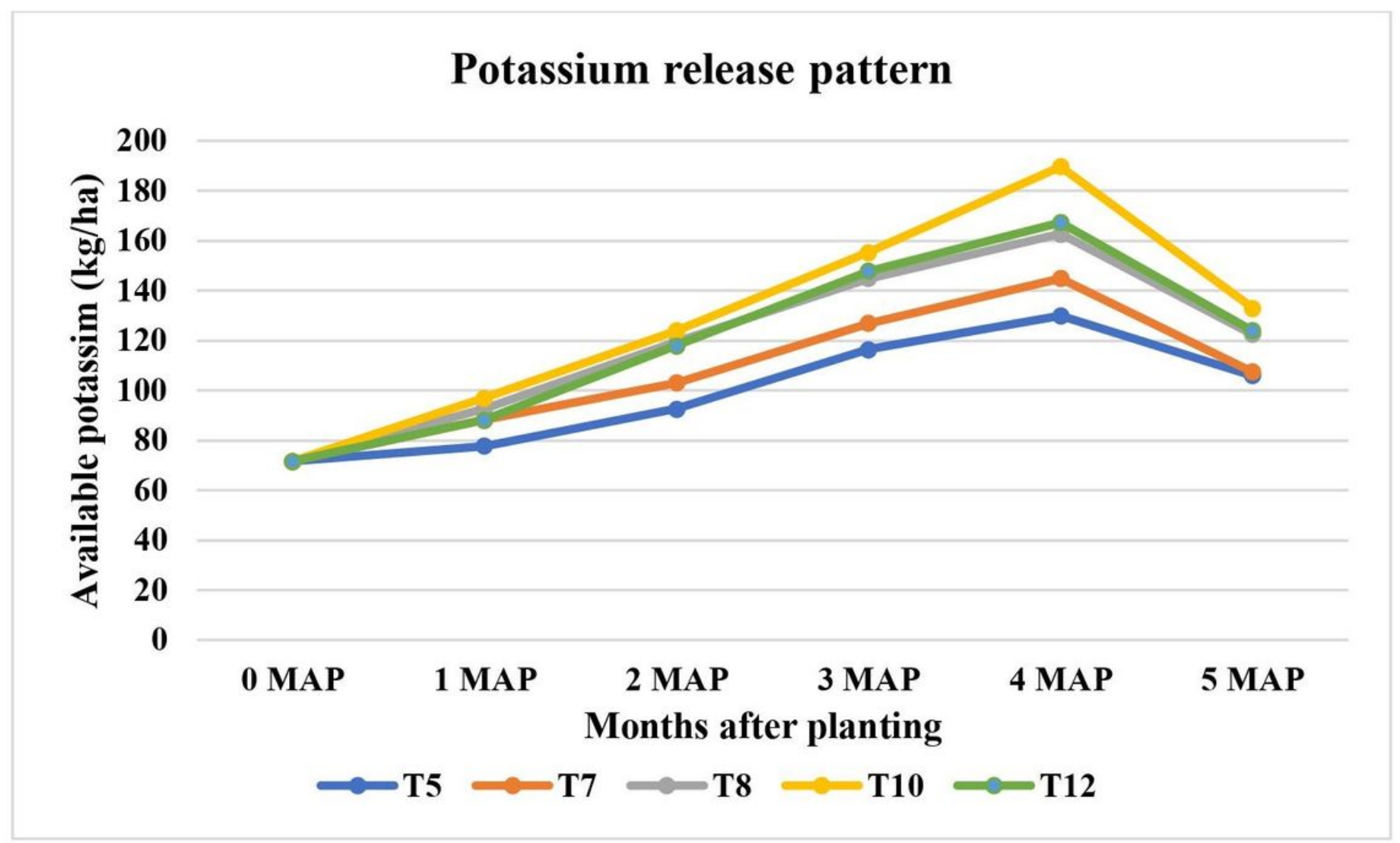

Figure 3

Effect of organic briquettes on available potassium $(\mathrm{kg} / \mathrm{ha})$ content of medium 